\title{
Decolonizing Agrarian Knowledge and the Emergence of Indonesian Critical Agrarian Studies
}

\author{
AHMAD NASHIH LUTHFI \\ Sekolah Tinggi Pertanahan Nasional Yogyakarta \\ Email: anasluthfi@stpn.ac.id
}

\begin{abstract}
Agricultural production growth has been the main priority in agrarian development in Indonesia but its ends and means have been varied. In the colonial era, an exportoriented colonial plantation system resulted in the transformation of the Indonesian land tenurial system. In the post-colonial period, Soekarno's regime pursued agrarian development seeking to strengthening people's land rights through its land reform policies. Land rights were seen as the basis for agricultural production. Soeharto's New Order regime implemented its Green Revolution policy by developing agricultural mechanization and extensification which managed to improve agricultural production, but it gave greater privileges to the rural elite class and caused dependence on foreign inputs and aid. All agrarian policies were supported by knowledge produced through the research of influential institutions and individuals, including critical responses against the impacts of the transformation of land tenure. In this context, knowledge in agrarian studies with its critical perspectives were reshaped as part of the process of knowledge decolonization.
\end{abstract}

\begin{abstract}
Abstrak
Peningkatan produksi pertanian merupakan perhatian utama dalam pembangunan agraria di Indonesia dengan tujuan dan cara yang berbeda-beda pada berbagai masa. Pasa masa Kolonial, peningkatan produksi pertanian ditujukan untuk kepentingan kolonial melalui sistem perkebunan yang meluas dan berakibat pada transformasi sistem tenurial Indonesia secara mendasar. Pembangunan agraria pada era Soekarno berorientasi pada pemenuhan kebutuhan pangan rakyat secara mandiri dengan memperkuat hak atas tanah mereka sebagai basis produksi pertanian. Salah satunya melalui kebijakan land reform. Hal ini berubah drastis pada masa Soeharto yang berorientasi pada mekanisasi dan perluasan lahan pertanian di bawah kebijakan Revolusi Hijau. Kebijakan ini berhasil meningkatkan produksi namun hanya menguntungkan kelas elit pedasaan dan mengakibatkan ketergantungan pada input dan bantuan luar negeri. Segenap kebijakan agraria tersebut didukung oleh pengetahuan yang dihasilkan melalui penelitian baik lembaga maupun individu berpengaruh, termasuk juga respon kritis terhadap berbagai dampak yang diakibatkan. Di dalam konteks inilah studi agraria dengan perspektif kritis muncul, bertumbuh dan memiliki andil dalam upaya dekolonisasi pengetahuan agraria di Indonesia.
\end{abstract}

Keywords: agrarian development; critical agrarian studies; knowledge decolonization

Kata kunci: dekolonisasi pengetahuan; pembangunan agraria; studi agraria kritis 


\section{Introduction}

Agricultural production growth has been the main concern in agrarian development in Indonesia since the colonial era, and in the post-colonial era under Soekarno, up to the days of Soeharto's New Order. Its ends and means have been varied. In the colonial time, efforts to to increase agricultural production were to serve colonial interests, by the extensive use of plantation systems. The development of colonial plantation systems resulted in the transformation of Indonesian land tenurial system, which included land owned by common people, communities, or royal entities. Agrarian development in the Soekarno era were oriented to making people capable of meeting their own needs by strengthening their land rights by land reform policy, land rights being seen as the basis for agricultural production. Land reform policy in the Soekarno era aimed to create agrarian justice and people's wellbeing. The situation changed drastically in Soeharto's time who based agrarian development on agricultural mechanization and extensification of agricultural areas under the Green Revolution policy. The revolution increased agricultural production but gave privileges to the rural elite class and caused a dependence on foreign inputs and aid.

All of these agrarian policies concerned with increasing agricultural production, rural development and transformation of land tenure (briefly named as agrarian policy) was supported by knowledge produced by influential institutions and individuals as part of their research work, including critical responses against the impacts of the land tenure transformation. In this context, knowledge in agrarian studies with critical perspectives was born.

Critical agrarian studies on Indonesia had been initiated in colonial times. The germ of these studies can be traced to the writings of Indonesians in the first half of the $20^{\text {th }}$ century, such as Semaoen (1925), Iwa Kusumasumantri (1927), Soekarno (1930), and some European leading intellectuals from the mid- $19^{\text {th }}$ century to the early $20^{\text {th }}$ century such as Douwes Dekker (1859), Van Deventer (1902), and Van Vollenhoven (1919), until the emergence of the idea of changing colonial agrarian laws through the establishment of the Agrarian Commission chaired by M. H. Thamrin (1935).

These writings had an influence on the development of critical agrarian studies in post-colonial Indonesia. Indonesian critical agrarian studies refer to all agrarian studies that produce discourses on social stratification and agrarian inequalities, as well as on agricultural organizations which seek transformation to a more just agrarian structure. Such a critical perspective had once been the mainstream perspective in in Indonesian academic research, but was supplanted during the New Order, due to the fact that the regime conducted a political purge on universities and a number of scientists, by technocratic approaches in agricultural and rural socio-political studies subservient to the developmentalist ideology of the Green Revolution. 
This writing explores the roots of the critical agrarian studies tradition in Indonesia. Critical agrarian studies were inspired by Marxist studies (in the last days of colonial era and at the beginning of the postcolonial era in Indonesia) and partly by studies on customary laws (limited to the colonial era and diminishing after independence). The studies were taught to students in loose way with its inter-disciplinary methods, considering that scientific disciplines were not as restricted as today. Some of those studies were used to criticize capitalism; other disciplines were drawn upon to provide a picture of the poor social conditions under the colonial regime. In postcolonial times, agrarian knowledge was produced through studies designed to provide deeper insights on the problems faced by rural agricultural communities; and served as a basis for organizing rural agricultural communities with practical research involving collaboration of campus researchers and agricultural associations members hence supporting the new agrarian system of the newly independent Indonesia.

We understand here critical agrarian studies as social commitment engagement on research and scholarship. Critical agrarian studies interrogate popular propositions critically and compose new ways of questioning (White 2011). These are simultaneously a tradition of research, thought and political action, an institutionalized academic field, and an informal network. Scholars and activists working in these traditions have dedicated themselves to constructing alternative forms of knowing and of acting in the world (Edelman and Wolford 2017: 4). So, the purpose of critical agrarian studies is to construct a better reflection of the lived realities of people (Akram-Lodhi 2018).

\section{Traditions of agrarian research in the colonial period}

Official agrarian research in the colonial time was conducted to further the interests of colonial agrarian policies, such as on the application of land taxes, information on indigenous land rights for developing colonial plantations, and on the condition of workers in colonial plantations during the Depression of the 1930s.

In the time of Raffles, research directed by Mackenzie (known also as the Mackenzie team) was conducted on the agrarian system of Java (Bastin 1954). The research was done on instruction of Lord Minto, the English colonial governor general, who intended to do a total reform of the land rent and crop share regulations. Lord Minto felt there was a necessity for new land taxes rules which would establish a new relationship between the colonial government and its colonized people. From this research, Raffles concluded that "From the investigations by the English government and from various facts collected by government officials, it is noted that in most parts of this island, both in eastern and western district, there is no treaty between 
local rulers and farmers, and the ruler was the only land owner." (Raffles, 2008: 88 ]. In addition to providing a domein verklaring (the concept of domain statement by state to claim control of most of the land in the archipelago), the results of the research provided to Raffles and the cadastral policy, which gives a picture of land area and farmers' numbers, enabled rent agreements to be concluded. Farmers were obliged to pay to the government rent for the land owned by the state. This revenue was seen as the payment of land taxes. The tenurial system, which had had various forms according to the feudal hierarchy, was transformed into land ownership derived from the western concept ofproperty or eigendom. The result was the drastic increase instate revenue by the rapid growth of land tax payments. In Java, the land rent system was enforced by Raffles at the beginning of 1815 . The next year witnessed a four fold increase in tax revenues worth millions of rupiah from various parts of Java (Bastin, 1960).

Comprehensive research was conducted by the colonial government from 1868-1869 on the land rights of indigenous people. The research findings were presented in the report entitled Eindresume van het Onderzoek naar de Rechten van den Inlander op den Grond (Final Resume of the Research on Indigenous Landrights) or known in its short form as Eindresume (Kano 1984). The research had twin objectives, first, the recognition of eigendom (absolute right) which communities held. With ownership rights, there was a possibility that the owners could have rent transactions with foreign parties that is, private plantations which wanted to invest in colonial countries. Private enterprises were intended replace the colonial plantation business monopoly. Second, those land areas which were impossible to be proven as owned by any individual were given the status of being state land, and they were likely to be rented to private companies (in the form of 75 year erfpacht rights [leasehold]). The research results provide a picture of the variety of tenurial systems at that time, including communal and individual land ownership. But the final results of the research were presented too late, after a liberal economic policy was implemented by means of Agrarische Wet/ Agricultural Law in 1870 (Staadsblad number 55, 1870; number 118, 1870). The latter policy included regulation on domein verklaring which facilitated foreign investment in plantation businesses. Those two research above were conducted in depth and was fundamentally erudite, but were in fact still subservient to the colonial government's and private sector's interests, and rather than assuring land access and developing indigenous people's wellbeing.

\section{The roots of critical agrarian knowledge}

In such an economic policy context and culture of research which supported colonial policy, there was no agrarian research which concerned the human 
side of agricultural research. Social sciences, particularly sociology useful for finding out the condition of the lower class people in Indonesian society, were not taught in the Netherlands Indies. Courses in sociology were given in Rechtshogeschool (Law Colleges) in Jakarta in 1924. The courses were given in the context of supporting generally the curriculum of legal studies. In 1934, courses of sociology were banned and were never taught again (Jaspan, 1960).

Two influences can be mentioned as being seminal to critical agrarian studies in this period. These are namely, writings (reports, essays, pamphlets, brochures, scientific articles) that were produced by researchers working in two traditions: Marxism and customary law.

Among those influenced by Marxism are Tan Malaka (1925), Semaoen (1925), Iwa Kusumasumantri (1927), Soekarno (1930). Tan Malaka wrote in his "Naar de Republiek Indonesia" in 1925 that the state (then national state) must be in control of land and agrarian resources. His most important point is that to ensure the agrarian future of Indonesia, land and other agrarian resources must not be controlled by or depend on foreign capital investments. In this text, he formulated the national program of Indonesian communists. In economy, he proposed programs of nationalizing factories, mines, forests, plantations, the abolition of feudal and particular lands, and the distribution of these lands to all Indonesians. Semaoen, nicknamed "Wongso", wrote Kitab Tani: Boekoe Kaoem Tani Indonesia (The Farmers' Manifesto: The Indonesian Farmers' Book), in 1925. Communist thinkers seemed to be focused on two targets, namely foreign/private investors and aristrocrats. In his book, Wongso expounds twenty-four demands on three main issues: land ownership and distribution, education of peasants, and village government organization. "It is demanded that particular lands were confiscated from the hands of landlords and distributed to peasants who live in those lands... [it is demanded] that the lands of Solo and Jogja kings were also taken away and distributed to local peasants." (McVey 2006: 221-223, fn 105-106).

Sumira Dingley is the pseudonym of Iwa Kusumasumantri. In 1926 he wrote pamphlets in French about the Indonesian peasant movement. A pamphlet published in English, The Peasant's Movement in Indonesia, was presented at the 1927 meeting of Krestintern, the international peasants' organization of the Communist International. After the meeting the pamphlet was then translated into Russian with the title Bor'ba krest'ianstva Indonezii in 1927. This pamphlet details the struggles and conflicts of peasants against European plantation companies, the weight of the tax burden, extensive land ownership and local "kings", activities of Chinese moneylenders and making the Muslim pilgrimage (Hajj). It highlights the plight of uneducated farmers who do not know their political rights and also the various experiences of peasant organizations. The resistance of the peasants in Indonesian history was a resistance to the exploitation of the peasants from the colonial structure 
and feudal structure (Luthfi, Razif and Fauzi 2010). The Dingley's work demonstrated the importance of a global network in confronting capitalism and imperialism. The book emphasized that Indonesia must be seen as fighting in the arena of global super powers, considering that the majority of its population are peasants who have their own popular movements.

Hatta wrote Ke Arah Indonesia Merdeka (Towards a Free Indonesia) in 1932. Hatta's ideas about agrarian affairs are concerned with the right to land. He emphasizes the importance of having the guarantee of ongoing land tenure through the recognition of the right to land. Hatta explained how land is central to production. The safety of the people is also closely associated with the right to land. An agrarian country is in principle characterized by collectivity and communal work. Land belongs to the people. Everyone is entitled to have as much land as needed required to sustain the lives of their household. Land should not be treated as a commodity and is therefore not allowed to be traded. To grant the right to land, three principles should be abided by. First, land should belong to the farmers and their family members who have tilled it. The people's right to farming land should be protected from exploitation and expropriation by loan sharks. Controlling other people's land by collecting the yields on the basis of usury, debt bondage, and the like should be prohibited. Such harmful agreement should be revoked and land should be returned back to its former owner. Secondly, the law should contain the provision to forbid individuals of owning more than five hectares. Third, companies should be under the state's control or ownership to be able to control the land that affects the lives and livelihood of many people. ${ }^{1}$

A number of European intellectuals were highly influential in causing Europeans to become concerned about the condition of people of the Netherlands Indies, who were suffering from the double exploitation of colonial and aristocratic-feudal systems. These intellectuals are namely, Douwes Dekker (Multatuli) in the second half of the 19th century (1859), then in the first quarter of the $20^{\text {th }}$ century, Van den Brand (1903), J. L. T. Rhemrev (1904), Van Deventer (1902) dan Van Vollenhoven (1919).

The report prepared by the High Attorney J. L. T. Rhemrev shook the public of the Netherlands Indies. His investigation in the second half of 1903 was under an official order of Governor General Rooseboom (1899-1904).

1) That was why when preparing the Indonesian constitution in sessions of the Investigative Board for Indonesian Independence Preparation Efforts (Badan Penyelidik Usaha-Usaha Persiapan Kemerdekaan Indonesia - BPUPKI, in his proposals on "Social Welfare", Hatta emphasized the necessity of a system that he called "economic democracy". He expounded this system in his seven proposals, among others "Economy has to be established as a common effort, on a collective basis" (point 3); "production branches that dominate the life of all people have to be possessed by the government" (point 4); "Lands are owned by the society, each individual has the right to use land areas necessary for maintaining his family's welfare" (point 5). Those points were the germs of the concepts in article 33 of the 1945 Indonesian Constitution (Kusuma, 2017: 187-8). 
The investigation was in response to the effect of the circulation of a brochure written by Van den Brand, a local attorney in Medan. Entitled De Miljoenen uit Deli (The Millions from Deli) (1902), it caused a scandal in the Netherlands. The brochure was a collection of stories from his advocacy practice experiences in Medan. With his sincerity and anger, and in a religious tone, Van den Brand gives a detailed picture on the terrors and blackmail against manual workers. The brochure caused a feeling of horror all over the Netherlands, a half of century after the Max Havelaar of Multatuli had appalled the public. Rhemrev was a high ranked official of the state. He was commissioned to do an in-depth investigation on the matter and his findings did not miss anything that had been described by Van den Brand. The Ministry of Colonial Affairs did not dismiss the investigation report, but did not want the report sent to the Dutch parliament. But all political parties of the parliament urged the contrary, and the resume of the report was presented to the parliament but Rhemrev's report was simply archived and there was no follow up from the government. The report ended up in a pile of archives. However, the public had already been told of the horrific conditions of manual workers in East Sumatera plantations (Breman, 1997).

Van Deventer was the main spokesperson who spoke of the "service debt" that the prosperity of the Netherlands had obtained from the balance (batig slot) of the colonial economy. The profits had not been given to the indigenous people andit was now the time to repay them. It was a whole new idea, that the Netherlands had to avow its responsibility for the poverty of most Netherlands Indies people. Such an idea began to spread and replaced the old notion since the $19^{\text {th }}$ century which saw that it was normal that the "colonial country has to bring gains to the motherland", which was contained in the advice of H. W. Muntinghe to Lieutenant Governor Raffles (Bremen, 1997: 2-3).

The most prominent work of Van Vollenhoven, De Indonesiër en Zijn Grond (The Indonesian and His Land) (1919), was a response to a bill which was to amend article 62 of the Regelingreglement (Regulations) on the policy of the Netherlands Indies government which was to be implemented in 1917-1919. The amendment bill proposed the abolition of the third paragraph which contained clauses on the protection of indigenous people's land rights. He declared clearly the dangers caused by the neglect of indigenous people's rights, “... this problem has its contribution in determining the solution for the question, are we in the Netherlands Indies to succeed in making justice and satisfaction true, or in inducing disorder and hatred." That was why he was critical in questioning the principle of domein verklaring. In his mind, this principle was a form of violence, he called it "a century of rights violations", because it ignored the rights of indigenous people over their lands. Customary lands in official documents were classed as "savage lands" or "waste lands" 
(woeste gronden), but customary lands were correctly named beschikkingsrecht (customary rights) which were held by indigenous people. As a prominent professor of customary laws, he showed that beschikkingsrecht could not be found in the Burgerlijk Wetboek (Civil Code), and could not be assimilated to recht van heershappij (lordship rights) in the West. But in all parts of the Indonesian archipelago, customary rights were the ultimate rights on lands. The rights could be held by a tribe (stam) or a group of villages (dorpenbond), or by a single village.

Critiques, demands and various condition changes in the first decades of 20th century contributed to the establishment of the Grondrecht Commissie (Commission of Land rights) in March 1935, whose end was to reform colonial agrarian laws by deeper reconsideration of various land rights held by various groups of indigenous people in customary laws. The commission was headed by M.H. Thamrin, and M. Yamin, was its first secretary, Koentjoro Poerbopranoto was its second secretary (then replaced by Dr Soekamto), Amir Sjarifuddin its third secretary, and its members were R.M.A.A. Koesoemo Oetoyo, R. Lukman Djajadiningrat, Hadi, and Soenario. To get started, they sent official letters to several parties asking for their inputs. Among those who replied with their ideas were Dr Soepomo, Dr Tjipto Mangoenkoesoemo, (Iwa) Koesoemo Soemantri, and Abdul Ghafur. Among those who were in the commission were graduates of the Rechtshogeschool of Batavia who had significant concerns about customary laws.

On 30 July 1935, the commission had prepared its reports on (1) regulations and laws on land (land rights according to customs, rights and obligations of indigenous people to land, agrarian laws, basics on Indonesische domein, prohibition against land expropriation, environmental rights); (2) the importance of land for society and the economy (significance of land, land area which can be cultivated, population, household and land availability, migration); (3) the relation of Indonesians to Indo-Dutch in the matters of owning lands (history and status of Indo-Dutch people); (4) decisions (Indonesian Agrarian Commission, ANRI collection).

Research on the life of plantations workers had been conducted by the government of the Netherlands Indies in 1939-1940. The Coolie Budget Commission, based on its research, produced a report titled Living Condition of Plantation Workers and Peasant on Java in 1939-1940. Of the 1182 plantations in East Java, Central Java and West Java, it took data from eighteen of them. The research aimed to provide practical recommendations on what had to be done in establishing basic wages of workers in the time of economic recession, so that the plantation economy might survive (Coolie Budget Commission, 1956 [translated]). Such research was necessary as a part of the process of creating knowledge on the lives of plantation workers and farmers upon which a standard budget might be formulated. From this knowledge, what 
could be created was the minimum standard of rust en orde (peace and order) so that agrarian unrest would be prevented on plantation sites. The research results provide a picture of the miserable condition of plantation coolies and factory workers (either male or female, children or adults), but not of the supervisors and technicians. The results show why workers' organizations in the postcolonial era developed so strongly among plantations workers (Kahin in Coolie Budget Commission).

These research results, critical reports of high ranking officials, pamphlets, brochures, from certain institutions, and also from historical actors of Indonesian and foreign history mentioned above, formed a legacy of the colonial period which contributed to the formation of critical agrarian studies in postcolonial Indonesia.

\section{Critical agrarian studies in post-colonial Indonesia}

From the various types of knowledge produced by prominent institutions, teams or individuals described below, the most significant research approach was that of empirical field studies to obtain veritable pictures on social realities, concerningsocial organizations, customary laws, agrarian social relations, etc. The approach included efforts to provide empirical descriptions of Indonesian society's economic institutions in the post-colonial era, such institutions were intended to be the antithesis of the economic institutions of the plantation which was basically a new system from the West introduced to Indonesian society. Such a system had to be reformed in accordance to what was demanded by the Constitution, and in the debates on the existence of plantation companies and land rights in preparing the 1960 Basic Agrarian Laws.

Since 1945, there were three initiatives of critical agrarian studies in Indonesia which came from universities, government institutions, and agricultural community organization. These studies were not done within a single discipline, as at that time scientific disciplines were not as specialized and exclusive as today. These studies still gave clear pictures on the injustices of the agrarian structure, rural and agricultural poverty, and rural development. Kampto Utomo called these studies sociography or the embryo of agrarian sociology or rural sociology which can be described as "social forms and processes in rural and agricultural societies, with the continuous awareness of the inseparability between the holistic research on society and nations, and reciprocal relation between rural society and non-agricultural sector." (Kampto Utomo, 1965).

These three initiatives which emerged at the beginning of Indonesian independence came from institutions which can be classed as higher education institutions, government services or institutions, agricultural community organization or political organizations. Facing limitation imposed by 
insufficient academic infrastructure and human resources, the practice and development of studies on agrarian issues (White, 2004). The emergence of similar research institutions however did contribute to the growth of critical agrarian studies. These include Sosiografi Indonesia (Indonesian Sociography) in Gadjah Mada University (UGM), Rural Research in the University of Indonesia (UI), Agricultural Institute of Bogor, and Padjajaran University; Kantor Gerakan Tani (The Farmers' Movement Office), Djawatan Pertanian Rakjat (The People's Agricultural Office, and Djawatan Agraria (The Agricultural Office) in the Department of Agriculture; Academic Research of Aliarcham (Utomo 1965). In addition, there was also research undertaken by the Seksi Agraria (Agrarian Section) of UGM and in its role in providing an academic basis for the bill of the Agrarian Foundation Regulation Act (Undang-Undang Pokok Agraria - UUPA) ${ }^{2}$, producing a studies series called Masalah Agraria (Agricultural Issues) by Mochammad Tauchid which were initially used as materials for agricultural training organizations(White, 2004).

Mochammad Tauchid was indeed a prolific writer and a teacher in the Taman Siswa. He was among the leaders at the beginning of the Indonesia Farmers Front (Barisan Tani Indonesia - BTI), and founded Gerakan Tani Indonesia (Indonesian Farmers Moverment). As the chief of the education and social economy section of the BTI, in 1947 he was also the main editor of the BTI magazine, Barisan Tani Indonesia, and wrote on various problems concerning farmers and rural areas. In an article entitled "Mentjapai Kemakmoeran dengan Modernisasi Pertanian” (“Achieving Prosperity through Agricultural Modernization”) (Tauchid, 1947) he formulated how agricultural modernization had to be done. Modernization was not merely a matter of machinery but of educating peasants to organize themselves (in modern institutions) and to realize the meaning of their citizenship. Cadre education and courses (at district to village levels) were held to increase agricultural skills but also for making farmers aware of their citizenship. Materials that he proposed to be included in such education and courses were among others: state politics, national movement history, psychology and sociology, farmers movement, workers movement, agricultural economy, land rights, military, working practice, and knowledge on agricultural cultivation.

Tauchid also wrote a hefty volume on Masalah Agraria sebagai Masalah Penghidupan dan Kemakmuran Rakyat Indonesia (Agricultural Issues as Indonesian People's Prosperity and Livelihood Issues) (1952, 1953). He prepared the work in Bogor when he was a member of the Dewan Perwakilan Rakyat-Sementara (Provisional Parliament). The work was initially to be written as a series of small volumes of cadre educational materials, and would be compiled into a larger volume for the 1953 BTI congress. But a schism within the BTI

2) Full title is Undang-Undang No. 5 Tahun 1960 Tentang Peraturan Dasar Pokok-Pokok Agraria 
emerged in the previous year, so that he published the work himself with Tjakrawala publishing house. In his work, he expounds various agrarian problems since the colonial period up to the 1950s. In his conclusion he presents the philosophy, perspectives and demands for developing Indonesian farmers. This work was used as a reference used in the preparation for UUPA (Yudhotomo, 2004).

Studies used in the preparation andformulation of the UUPA were also important. Various seminars, studies and discussions were held for formulating theUUPA). Those activities were held in 1948, 1951, 1956, 1958 and 1959. Over this long period various successive committees were formed such as Panitia Agraria Yogya (Yogya Agrarian Committee), Panitia Agraria Jakarta (Jakarta Agrarian Committee), and Panitia Sewahjo(Sewahjo Committee) which had issued two bills namely the Soenarjo Bill and Sadjarwo Bill. The core purpose of the establishment of a new agrarian law was to replace the agrarian law which had been inherited from colonial times (Harsono, 2007).

The final bill of the UUPA (1958) was debated by the various political parties in the parliament, which led to general seminar being held. The Agrarian Ministry then commissioned a number of persons to do thorough research on the matter and prepare an analysis which was to be presented in the seminar to be held from 19-22 November 1958 in Tretes, Jawa Timur. The researchers were Drs Soerjadi, who was assigned to analyze the relationship of the UUPA to the state's economic development; Kampto Utomo, on rural society development, and; Sudiharto Sastromidjojo on credit. The results of Tretes seminar left an unfinished research agenda that is, arguments on the determination of the minimum and maximum area of landwhich could be owned by an individual (Printono, 1965).

In the Tretes seminar, the Seksi Agraria of UGM presented a discussion paper and changes for the the UUPA bill (the Seksi did not attend the seminar so that their paper was circulated to participants as a report). The Minister of Agraria in letter No. Unda/1/3/10, of 4 July 1953 demanded officially the Seksi play a more significant role to "ensure an objective scientific angle" on the bill. The Seksi had prepared a paper for considerations with proposed changes. This contribution of the Seksi was based on their research activities through an agrarian enquete (inquiry) in both Central and East Java in 1953. The enquête was undertaken by students with "aid from all officials of local government, residents, district chiefs, sub-district chiefs, sub-district chief assistants and directors of local agrarian services." With methodological limitations and ways for grasping agrarian condition of society, it was admitted "that by holding an agrarian enquête, the field researchers felt they had beengiven a good opportunity methodological guides to gain some deeper knowledge... the enquête was an education in practical research activity." 
Enquête agrarian research was done with the support from the Ministry of Domestic Affairs and recognised by the Ministry of Agraria. The research Indonesia was cancelled due to technical and financial problems." (Reports of the UGM President 1954/1955).

In addition, inputs for the UUPA were also based on courses given by the Seksi Head, Professor Drs. Notonagoro. Since 1949, he had been teaching Agrarian Laws and Politics, whose standpoint was that the new agrarian laws "had to be adapted to the independent environment and the spiritual principles of the Indonesian Republic", as well as "the agrarian laws had to fit itself to the present agrarian reality” (Soetiknjo, 1987).

Here we see that research and the knowledge it generated were used for supporting norms, policies and the birth of a regulation that created a new agrarian order in the post-colonial era, supplanting the old one which was contrary to the spirit of independence. The experience gained from the long process in formulating the UUPA, involving the government, parliament and the UGM's Seksi Agraria, shows that the perception and imagination related to agrarian laws, suited to all Indonesians, not only constitutes an external project, an antithesis to colonial laws, but constitutes also an internal project of transcending claims and interests of the three parties in the parliament: nationalist, religious and communist. In its methodology, what was done was to resystematize and provide an ethical basis that applies Pancasila to the UUPA. This takes into account that Pancasila is the spirit of the nation and the basis for the Indonesian state, harmonizing the new agrarian laws to customary laws (Soetiknjo, 1994).

White (2004) also showed the importance of the role Sosiografi Indonesia dan Hukum Adat (Indonesian Sociography and Customary Law), a journal of UGM. The journal had its first issue in 1955. Up to 1951, the close relation of sociological studies to legal studies was prominent, and members of the editorial board included law experts (meester in de rechten), such as Professor Dr M. M. Djojodigoeno (chief), Wahjoeddin Widjaja (secretary), and members Soedarso, Soemardjo Hadiwignjo, Sarwono, Kaharkoesman, and Pandam Goeritno.

The journal produced a very rich range of studies, including a number of monographies at village and sub village levels. Among its thirty studies, the majority were about Java, and the others being two studies on Sulawesi, three on Sumatera, one on Kalimantan, and three on Bali. The problems studied covered agriculture, economic life, class structure, rural leadership and government, social beliefs, population's life levels, kinship structure, and others (Utomo, 1965: 269). Its field research showed many examples of social stratification based on the inequality in landownership, which was not based on shared poverty, as assured by Clifford Geertz (White, 2004).

Sosiografi Indonesia (Indonesian Sociography) was a magazine journal 
founded by the Panitya Sosial Research (Social Research Committee) of Gadjah Mada University. The committee was established in 1951, in collaboration with a field research team from Massachusetts Institute of Technology (MIT). This collaboration however, cannot be separated from the context of the Cold War and the efforts of the US to propagate social sciences which were Western- or, more accurately, American-oriented. The team was led by Rufus Hendon and had seven PhD candidates of Harvard University, namely Clifford Geertz, Hildred Geertz, Robert Jay, Donald Fagg, Edward Ryan, Alice Dewey and Lea Williams. Having obtained his doctorate degree, Donald Fagg committed suicide for reasons unknown. His family did not permit the publication of his dissertation on modernization and bureaucracy (Tjondronegoro, 1983). The collaboration did not go smoothly and according to Clifford Geertz (Geertz, 1988) the breakup of the UGM-MIT collaboration was caused by the UGM's proposal that the team should pick Wonosobo as its research site. The mountainous area of Wonosobo was known with its scarcity of rice. MIT team preferred Pare, Kediri. Despite the collaboration endingUGM continued its own research activities with Sosiografi Indonesia as theoutlet for research results.

The cold war context was a very significant e factor in the development of knowledge within academic institutions, especially in the newly established agricultural faculties. The Council on Economic and Cultural Affairs (CECA),founded by Rockefeller III, had as its main goal "developing and providing agricultural economy training” in Indonesia. John Lossing Buck was the then director of the CECA and his successor was Arthur T. Mosher. They both censured books donated to Indonesia.

Some agrarian studies, based on field studies in Bandung and Bogor, noted the role and collaboration between Dutch and Indonesian scientists. The first is a study on land ownership and relations between poor and rich farmers in West Java, conducted by Anwas Adiwilaga in 1954. It was a continuation of research done by H. Ten Dam (Amsterdam) in Cibodas however,Adiwilaga selected another site for his study, namely Tjipalago, Bandung.

He was an economist, and was able to observe aspects of land ownership on site, hence he could directly describe the differentiation that took place. He was known as a professor who introduced rural sociology at the University of Padjadjaran. He accompanied W. F. Wertheim in the latter's subsequent visit to Cibodas. They both witnessed the way farmers using slopesemployed tactics in dealing with a planting contract imposed by forestry services there. They destroyed the newly planted pines in the night so that the service had to replant, hence not hindering the growth of their own plants. Such an act was a sign of land hunger.

The second is a study conducted by H. Ten Dam with Kampto Utomo 
and students and professors of the agricultural faculty of UI in Bogor (19501954). The research was on society's social structure and local agricultural organizatons, namely cooperatives. They described the history of villages which were formed at the end of 19th century, inside forest areas, by peasants who came from villages around Bandung. The study explained the structure of Cibodas village. It consisted of two different social groups with their fundamental difference being on account of their access to land, which determined their economic activities and social status. The first group were servants or "those who dedicated themselves", while the second consisted of those who orderor "who have serfs" (Ten Dam in Wertheim 1961). More or less $90 \%$ of families in the village were agricultural workers.

Cibodas was once visited by the Vice President Hatta in the framework of enhancing the cooperative movement. The research and the experience of the vice-presidential visit gives us an understanding that the idea of unifying people in a cooperative with members who were economically and socially unequal but would merely result in organizational disparity.

Two agrarian studies form Bogor conducted by Bachtiar Rifai and Kampto Utomo was supervised by Professor W. F. Wertheim. Rifai's dissertation was titled Bentuk Milik Tanah dan Tingkat Kemakmuran: Penyelidikan Pedesaan di Daerah Pati, Jawa Tengah (Forms of Land Ownership and Levels of Prosperity: Village Research in the Area of Pati, Central Java) (1958). While Kampto Utomo study was titled Masyarakat Transmigran Spontan di Daerah W. Sekampung (Lampung) (An Unplanned Transmigration Community in Kampungs in Area W(Lampung)) (1957).

Utomo's dissertation presents a sociological-anthropological description of pioneer farming communities in South Sumatera (Lampung). They initially came to the locations as part of the government program's planning framework, but then they spontaneously moved to new locations to open up their own agricultural areas. The newly opened places then became new "Javanese villages" which developed village units similar to those in Java (the established relation of sub-district to the district government).

Utomo's study made use of a more anthropological perspective (rather than a sociological-anthropological one) due to the scarcity of sociological literature in the first decades of the postcolonial era. Additionally at this time,works on sociology were unavailable. The agricultural faculty of the IPB sent a letter requesting copies of 118 works to the CECA but itwas only partially met. The requested books which included classical sociology works such as those byCooley, Weber, Merton, Hogbins, Gerth, Mills and Wertheim were refused however,hose those by Parson, Lazarfeld and Geertz were approved (White, 2004). Therefore, in his efforts to learn about sociological knowledge of villages, Utomo drew upon the journal, Current Anthropology. He utilized anthropological methods in his research: observing daily lives, 
digging out life histories, using participatory observation, and studying village archives (Luthfi, 2010).

To gain an understanding of the agricultural and agrarian education tradition in Bogor in the post-colonial era, we can study the academic training of Kampto Utomo (who changed his name to Sajogyo) (Luthfi 2011). In 1949 Kampto Utomo enrolled himself in the faculty of agriculture of UI located in Bogor, which became the Institut Pertanian Bogor (IPB) (Bogor Agricultural Institute) in 1963. In the faculty, he took socio-economics of agriculture as his major. He learned the traditions of natural sciences and humanities (Wahono, 2005). He attended the courses of Professor Teko Sumodiwiryo, an expert in the field of promoting cooperatives in the 1930s; of D.H. Burger on Netherlands Indies bureaucracy and politics; of Ir. Terra (a horticultural expert) on agricultural enterprise with ethnological analysis, in which the garden was of a "matriarchal pattern" and pasture areas were a "patriarchal one". Van Aartsen taught him economic geography in the context of world economy. Bloembergen (a botanist) taught him on "plant geography". Professor W.J. Timmer gave him insights on "social agronomy". His dissertation was supervised by ProfessorWertheim (sociology) from 1955-1957 (Sajogyo, 2004). It can be said that the teaching activities in IPB of the time contained a mixture of various materials and scientific disciplines, dominated by Dutch professors and the use of handbooks in Dutch, even in German (especially for the subject on cooperatives).

The experience of Timmer himself was unique. He was a magister (masters degree holder) until 1951 in the agriculture faculty of the UI in Bogor. He was the initiator of what was called social agronomy. With his background as an insinyur (engineer) of agriculture in Wageningen, Holland and an agricultural consultant, he developed this new approach in his doctoral dissertation in the University of Indonesia (1947) with Professor Boeke as his supervisor. His approach was then perfected in a voluminous work entitled Totale Landbouwwetenschappen (Bogor, 1953) which presents a comprehensive explanation of social agronomy including its basic philosophy. The work gained rapidly international recognition, and was translated into English in 1982 with the title Human Side of Agriculture, emphasizing an approach usingagricultural counseling theory and practice (Sajogyo, 2004).

Knowledges produced by IPB's agricultural faculty was marked by their teaching not merely technical matters of agriculture but also giving stronger emphasis on socio-economic subjects. Later on when Timmer became the director of IPB in 1965, he made courses on the sociology and economy of agriculture compulsory in all faculties. The students were not only taught theories but had to go to the field for learning together and accompanying the village population. Mass counseling was the continuation of the Demas (demonstrasi massal) (1964), in which a number of agronomy professors 
along with their students conducted an experiment on 100 ha of rice field in Karawang, a pilot project site of national agriculture. The initial experiment was successful, so that the mass counseling was directed by government to be a compulsory course for all students of the agricultural faculty and one of the requirements for the final assignment.By the end of 1965 the course had been attended by 1400 students for a few months in some villages.

In his service as the director of the IPB (1964-1972), Utomo was appointed by the government to be the chairman of the Badan Kerja Survey Agro Ekonomi (Agro-economy Survey Working Board (SAE). This institution was commissioned to "study agricultural resources and rural agricultural society's condition in Indonesia, and also on rural agricultural organizations, services and government programs in agricultural and agrarian fields at all levels of government." SAE was the result of the idea of the then Minister of Agraria Sadjarwo, due to his being not satisfied with the result of the 1963 agricultural census which did not include those people who owned each less than $1000 \mathrm{~m} 2$ as farmers. The reality of small farmer was not presented in the census.

Sediono M.P. Tjondronegoro joined the professorial rank of the IPB after his graduation from Amsterdam University (1963). He realized that there were differences between the European and the American university systems. In Europe, he experienced an education which was elite in nature, but that in America was massive, open education to all classes in society (where he completed his masters program in 1968). In Europe, what was deemed essential were qualitative and theoretical analyses, while in America the system placed emphasis on quantitative analysis and statistical/survey methodology. In IPB he felt the changes with the abolition of a number of field courses, despite the fact that those courses gave opportunities to students to have direct experiences of rural communities. He was very much impressed with the activity of learning together with rural people, "By living in rural areas, students can live the life of agricultural people: what they complain about; their thoughts; customs; what problems they are facing; and what kind of happiness that they feel. Such an experience cannot be grasped from the reports of village chiefs or sub-district chiefs" (Tjondronegoro, 2008: 123).

Another feature of IPB teaching was its interdisciplinary method. David Penny, who began to work as a researcher of agricultural development in the early 1960s in Indonesia, perceived the approach developed by Bogor scientists and recalled Sajogyo's words to him, "If you want to understand the economy of my country, study our culture and our political system; if you want to understand our culture and our political system, study our economy" (Penny, 1984).

In addition to interdisciplinary studies, Sajogyo also placed emphasis on inter-sectoral collaboration among academics, society counselor and 
government officers. He stressed that the problem must be thoroughly understood and solutions found. Rural or agrarian sociology that he developed did just do task which were descriptive but also prescriptive in nature. In other words, the task of sociology is not only to explain the reality, but to change the reality. He founded an association of scientists called Perhimpunan Ekonomi Pertanian Indonesia PERHEPI) (Indonesian Agricultural Economic Association, whose members were not solely economists but also everybody who had interests in the study of agricultural socio-economy and who were from different disciplinary background.He did not even require any academic qualifications for membership.

The study conducted by Aidit and his team of 40 persons was very wide ranging. The study analyzed the class divisions in rural areas, current forms of exploitation against the peasant and fishermen class, and the political power that they named setan desa (village satans). In another part of the study, it outlined how peasants should fight to improve their situation : their economic fights, forms and processes of organizing actions, methods and principles of propaganda, improving revolutionary culture and morality, up to the institutional functions of a village in the forms of cooperatives, granaries for dealing with drought, and arisan (women's social clubs).

In methodological matters, there are some things which are interesting. The research was participative, and such method is discovered based on strong sensitivity and understanding of peasant communities. Based on three principles tiga sama (three together) -working, eating and sleeping together with agricultural workers and poor peasants - the research was oriented more to organizing peasant movements. Such an orientation was reflected in the saying "intensify integration with research" (Aidit, 1964). The study was done in twenty-seven sub-districts insixteen districts in West Java. Their ideological formula called 'seven rural devils', despite having a high risk of causing conflicts, is in the eyes of Ben White the result of research which was "realistic and accurate in the time" (White, 2004).

Dozens of undergraduate theses on land reform were produced in the Akademi Agraria Yogyakarta (AAY) (Yogyakarta Agrarian Academy), now the Sekolah Tinggi Pertanahan Nasional (STPN) (National Land School). The academy was founded in 1963 with its main mission being to execute the orders of the UUPA of 1960. The program of land registration was taught in Semarang, while the Land and Land Reform program was conducted in Yogyakarta. Since its beginning, students of the AAY were supposed to prepare their undergraduate thesis on land reform which was taking place then (in the mid-1960s), either on its implementation or on its possible impacts. From 1966 to 1983, the land reform theme was still being discussed in these theses. A small number of undergraduates theses from the first generations of students of the AAY have been digitalized (STPN-ARC, 2017). 
A separate study is necessary for reviewing these hundreds of theses, so that their orientation and changes can be analyzed to find kind of New Order's land reform.

In the New Order period agrarian development was oriented to increasing agricultural production and abandoned the lower classes of population,with itsreliance on capital and technological powers in the grand agenda of the Green Revolution. Such development in those days became characterized by the expression 'modernization without development' (Sajogyo, 1973). And it was the moment in which critical agrarian study began loose its significant place in agricultural and social sciences in Indonesia.

\section{Conclusion}

The project of decolonizing knowledge generally needs efforts to search for and rediscover indigenous knowledge of colonized communities. The phrase 'indigenous knowledge'(Linda Tuhiwai Smith, 2008) or the 'national perspective' and becoming part of something which is promoted.

The critical knowledge inherited from Indonesian figures influenced by Marxist thought (communists, nationalists, and democratic socialists), and other prominent European figures in the colonial era cannot be neglected. This also applies to contributions of Indonesian legal scholars who were educated by the Dutch government, especially those who focused their studies on customary laws and the real condition of Indonesians. Knowledge of colonialism was based on a conviction that colonized lands, including its agrarian resources, were supposed to serve the interest of the colonizing country. This conviction had been destroyed in the mid-19th century and the critique against it got stronger in the first half of the $20^{\text {th }}$ century. The decolonization had been challenging the status quo long before the collapse of colonialism. Decolonization is a struggle and not a signifier of an episode.

The contribution to decolonization of agrarian knowledge came for academics and intellectuals who taught in the IPB, those who made use of interdisciplinary perspectives such as Terra and Timmer, and of critical sociology such as Wertheim.

The deconstructive nature of their contributions against agrarian colonial knowledge in the era of Indonesian independence is not found at anational identity which is romantic in character, but in its methods and purposes: empirical and emancipative. Empiric study is for grasping the real condition of Indonesians, with all their agrarian problems which they inherited from colonial and feudal systems. The emancipatory vision of their contribution is to dismantle and remove all those obstacles. Research and knowledge production has been done and published by various parties namely higher education institutions, government institutions, peasant community organizations or political organizations. The significance of their expertise 
was challenged then, their research was conducted with great conviction by different parties. In the words of Achille Mbembe, the authority shifts from university to pluriversity, and we witness here the strategy of openness to dialogue among different epistemic traditions. Methods, visions, and epistemic openness can be named as the power for developing critical agrarian studies amidst limited infrastructure and skilled human resources in those days. With an openness to dialogue the critical agrarian study may continue to play its role in liberating the whole Indonesian nation.

\section{References}

\section{Unpublished Archives}

ANRI, Komisi Agraria Indonesia 1935.

\section{Books}

Bastin, John Sturgus (1954). The Development of Raffles's Ideas on The Land Rent System in Java, Netherland: Gravenhage.Breman, J. 1997. Menjinakkan Sang Kuli: Politik Kolonial, Tuan Kebun dan Kuli di Sumatra Timur pada awal abad Ke-20. Pustaka Utama Grafiti.

\section{Articles}

Boomgaard, Peter (2006). 'The Making and Unmaking of Tropical Science Dutch Research on Indonesia, 1600-2000', Bijdragen tot de Taal, Land-en Volkenkunde (BKI), 162-2/3.

Coolie Budget Commission (1956). Living Condition of Plantation Workers and Peasant in Java in 1939-1940 (translation from Dutch by Robert van Niel). New York: Modern Indonesia Project Cornell University.

Dam, H Ten (1961). 'Cooperation and Social Structure in the Village of Chibodas', in W. F. Wertheim (ed.). Indonesian Economics, the Concept of Dualism in Theory and Practice. The Hague: W. van Hoeve.

Edelman, Marc and Wendy Wolford (2017), Introduction:Critical Agrarian Studies in Theory and Practice, (Antipode Foundation Ltd)

Geertz, Clifford (1988). 'Recollection of an Itinerant Career'.Bulletin of Indonesian Economic Kajianes, Vol. 24, No. 3.

Harsono, Boedi (2007). Hukum Agraria Indonesia: Sejarah Pembentukan UUPA, Isi dan Pelaksanaannya, Jilid 1. Jakarta: Djambatan, $11^{\text {th }}$ printing.

Jaspan, M. A. (1960), Social Stratification and Social Mobility in Indonesia. Jakarta: Gunung Agung.

Kahin, George McTurnan (1956). "Preface", in Coolie Budget Commission 1956, Living Condition of Plantation Workers and Peasant in Java in 1939-1940 (translation from Dutch by Robert van Niel), New York: Modern Indonesia Project Cornell University.

Kano, Hiroyoshi (1984)."Sistem Pemilikan Tanah dan Masyarakat Desa di Jawa pada Abad XIX”, in Sediono M.P. Tjondronegoro dan Gunawan Wiradi. Dua Abad Penguasaan Tanah: Pola Penguasaan Tanah Pertanian di Jawa dari Masa ke Masa, Jakarta: Yayasan Obor Indonesia

Kusuma, AB. 2017, Menggugat Arsip Nasional tentang Arsip Otentik "Badan Penyelidik" dan Panitia Persiapan Kemerdekaan Indonesia, Jakarta: Badan Penerbit Fakultas 
Hukum Universitas Indonesia

Akram-Lodhi, A. Haroon 2018, "What is Critical Agrarian Studies?", https://roape. net/2018/03/28/what-is-critical-agrarian-studies/, accessed on January, 30 2020

Luthfi, Ahmad Nashih 2011, Melacak Sejarah Pemikira Agraria: Sumbangan Pemikiran Madzhab Bogor, STPN Press, Pustaka Ifada, Sajogyo Institute

Luthfi, Ahmad Nashih and M. Fauzi, Agrarian Chronicles in Indonesia: Expanding Imagination over Periods, Sectors, and Actors, Yogyakarta and Jakarta: STPN Press and Konsorsium Pembaruan Agraria

Mbembe, Achille. 2015. "Decolonizing Knowledge and the Question of the Archive.” Public lectures given at the Wits Institute for Social and Economic Research (WISER), University of the Witwatersrand, Johannesburg

McVey, Ruth T 2006, The Rise of Indonesian Communism, Singapore: Equinox Publishing

Mohamad, Goenawan et.al 2003, Menyambut Indonesia: Lima Puluh Tahun bersama Ford Foundation (1953-2003), Ford Foundation dan Equinox Publishing

Oudejans, Jan H.M. 2006, Perkembangan Pertanian Indonesia (Yogyakarta: UGM Press

Penny, D.H. 1984, Hints for Research Workers in the Social Sciences. Ithaca, New York: Center for International Studies and Dept. of Agricultural Economics, Cornell Unievrsity

Printono 1965, Undang2 Pokok Agraria, Landreform, Bandung: Penerbit "Dua R"

Raffles, Thomas Stamford, 2008 (Indonesian translation by Syafruddin Azhar) The History of Java, Yogyakarta: Narasi

Sajogyo 1973, "Modernization without Development in Rural Java”, paper on seminar Agrarian Transitions, Bangkok: FAO

Sajogyo 2004, "Membangun Wawasan, Mengikat Janji”, Pidato Akademik pada Peresmian Selo Soemardjan Research Centre FISIP UI, Jakarta, 15 Juni

Smith, Linda Tuhiwai 2008 (translation), Dekolonisasi Metodologi, Yogyakarta: Insist Press

STPN-ARC 2017, “Digitalisasi Skripsi Landreform” (CD 2017)

Tjondronegoro, Sediono M.P. 1983, "Penelitian Ilmu Sosial dan Penentuan Kebijakan", Prisma, 6, Juni

Tjondronegoro, Sediono MP 2008, Mencari Ilmu di Tiga Zaman dan Tiga Benua: Otobiografi Prof. Dr. Tjondronegoro, Bogor: Sains Press

Utomo Kampto 1965, "Research Sosiologi Pedesaan di Indonesia, 1945-1965”, in Sadikin Soemintawikarta (Ed.), Research di Indonesia, 1945-1965, Bidang Pertanian (III), Jakarta: Departemen Urusan Research Nasional Republik Indonesia

Wahono, Francis 2006, "Pendahuluan: Teori Terbentuk karena Aksi”, in Sajogyo, Ekososiologi, Deidologisasi Teori, Restrukturisasi Aksi (Petani dan Pedesaan Sebagai Kasus Uji, Yogyakarta: Cindelaras Pustaka Rakyat Cerdas, Sains, and Sekretariat Bina Desa

White, Ben 2005, "Between Apologia and Critical Discourse: Agrarian Transition and Scholarly Engagement in Indonesia”, in Vedi R. Hadiz dan D. Dhakidae (Eds.), Social Science and Power in Indonesia (Jakarta: Equinox with ISEAS) White, Ben 2011, "Critical Agrarian Studies: Basic Concepts”, Short Course Agrarian Transitions session A2

Yudotomo, Imam 2004, Kakung-Uti: Moch. Tauchid-Kastariyah, Catatan untuk Cucucucunya, unpublished manuscript 